\title{
Deux ou trois choses sur l'irrigation dans un village des Andes sèches
}

Olivier Dollfus

\section{(2) OpenEdition \\ 12 Journals}

Édition électronique

URL : https://journals.openedition.org/tc/917

DOI : $10.4000 /$ tc. 917

ISSN : 1952-420X

Éditeur

Éditions de l'EHESS

\section{Édition imprimée}

Date de publication : 1 septembre 1986

ISSN : 0248-6016

\section{Référence électronique}

Olivier Dollfus, « Deux ou trois choses sur l'irrigation dans un village des Andes sèches », Techniques \& Culture [En ligne], 7| 1986, mis en ligne le 23 janvier 2006, consulté le 29 septembre 2022. URL : http:// journals.openedition.org/tc/917 ; DOI : https://doi.org/10.4000/tc.917

Ce document a été généré automatiquement le 29 septembre 2022.

Tous droits réservés 


\section{Deux ou trois choses sur l'irrigation dans un village des Andes sèches}

Olivier Dollfus 